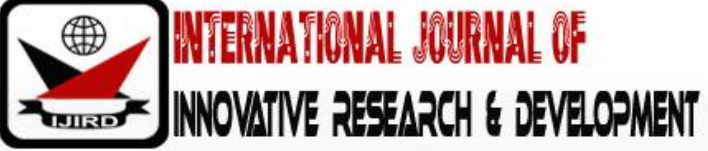

ISSN 2278 - 0211 (Online)

\section{Services Quality Model for Attracting Patronage for Fast Food Restaurants: Study of FCT, Abuja Nigeria}

\author{
Dr. Jude E. Madu \\ Senior Lecturer, Department of Marketing, Baze University, Nigeria \\ Surraya Ahmed Abdulkadir \\ Lecturer, Department of Marketing, Baze University, Nigeria
}

\begin{abstract}
:
The high population of youths in Abuja portrays an opportunity for profitable patronage for Fast Food Restaurants in Abuja. Unfortunately, many of them are out of business because of low profit as a result low patronage. Many efforts have been made to savage the industry but to no avail, hence the need for a Services Quality Model. To realize this, secondary data was obtained through the Internet, Test books, and Journals, while primary data were obtained through a Questionnaire distributed to youths residing in Abuja. Primary data obtained was tabulated and analyzed through the percentage method. Major findings include: (a) few employed and undergraduate youths patronize the Fast Food Restaurants because they don't have time to cook, and when they want to socialize with friends; (b) major factor that attract youths preferred Restaurants are fresh food in big quantity with moderate prices, always available variety of food, neat and cool environment, friendly personnel and less steps for ordering and receiving food; (c) major external environmental factors against the Fast Food Industry include: insecurity in the country, inflation, high interest rate/ tax regime, high cost of doing business in the country, dominance of 'Mama put', and lack of modern technology. Based on the findings, the recommended Marketing activities are summarized under the five fundamental factors for measuring Services Quality; reliability, responsiveness, tangibles, assurance and empathy. Also recommended is the use of the Marketing tools to counter the possible effects of the threats from the external environment.
\end{abstract}

Keywords: Services quality, model, customer patronage, youths, fast food restaurants, environmental threats.

\section{Background of the Study}

Abuja, the Capital City of Nigeria is located in the center of the country Nigeria with the Federal Capital Territory (FCT). Abuja is a planned city build mainly in the 1980s to replace Lagos as the Federal Capital as a result of over growing population of Lagos. The Federal Capital Territory formally moved to Abuja on 12th December, 1991. Result of the 2006 census shows that the city of Abuja had a population of 776,298, thus making it one of the few most populous cities in Nigeria. According to the United Nations reports on population and Development (2016), Abuja grew by $139.7 \%$ between 2000 and 2010, making it the fastest growing city in the world. As at 2015, the city of Abuja was experiencing an annual growth of at least $35 \%$. This made the city retain its position as the fastest growing city in the African Continent and one of the fastest growing cities in the world. Abuja has witnessed a high influx of people into the city; this increase in population has led to the emergence of satellite towns such as Karu Urban Area, Suleja, Gwagwalada, Lugbe, Kuje, Nyanya and even Mararaba of neighbouring State of Nasarawa. The United Nations official metropolitan area of Abuja has a population of over three million five hundred persons (3.5million) with about $70 \%$ as youths, thereby making it the fourth largest metropolitan city in Nigeria surpassed by Lagos, Kano and Ibadan. As at 2016, the metropolitan population of Abuja is estimated at about six million persons $(6,000,000)$ with about $72 \%$ of the population comprising the youths and placing it behind Lagos as the most populous metropolitan Area. It is worthy to note that apart from being the Administrative and Political centre of the country, housing all Federal Ministries and parastatals, Abuja is also housing and hosting so many international organizations and conferences. Apart from an outburst of markets, many business organizations have been established and are still establishing in Abuja. The city of Abuja is currently housing seven (7) Universities, one (1) Polytechnic and several other post secondary institutions. The significance of this is that the population of the youths is high, thereby creating a substantial market for fast food restaurants in Abuja.

Fast Food Restaurants (also known as Quick Service Restaurants) are retail outlets where food of assorted types is quickly produced and served. Food is a material consisting essentially of protein, carbohydrate, and fat used in the body of an organism to sustain growth, repair and execute vital processes and to furnish energy for humans. A good food is expected to contain the classes of food which include: Carbohydrates, Protein, Minerals, Fat and Water. Ayeni (2016) notes that even if a food contains all the classes of food, such food need to be produced, preserved, served and consumed in an environment that is not polluted. This issue of environmental pollution is what gives fast food restaurants an edge to the 
popular "mama put" which usually operate along the road sides or public open places and spaces without regulation and regard to environmental pollution. Anyanwu and Inyanga (2006) state that environmental pollution is inimical to good health which food is aimed to achieve. Given the polluted environment in Abuja which is as a result of human and animal defecations, litter of used and decaying packages, poisonous gas emissions from old cars, Lorries, generators and motorcycles or tricycles, food should be consumed inside restaurants where environmental friendliness is guaranteed. Good food enhances growth; therefore, food is mostly needed by youths. Youths are persons between childhood and adults; especially they can be described as persons between the ages of 18 - 45 years. They are young, vibrant, and energetic in reasoning and actions. They are more vulnerable to hunger and need a lot of food to grow. Because of the increasing need for food by youths, the patronage for Fast Food Restaurant is expected to be on the increase, otherwise there is a problem that requires an immediate solution.

\section{Problems of the Study}

Stanton (1981) describes market as "people"; that means the population of persons in an area determines the attractiveness of patronage for a particular product. The population of youths and the increasing influx of youths into Abuja should be an advantage for increasing patronage for Fast Food Restaurants in Abuja. Unfortunately since the past three years, many Fast Food Restaurants in Abuja have folded. The few that still exist are merely crawling in terms of returns on investment. They find it difficult to realize their operating costs; hence profit making is a mirage. Even the multinational Fast Food Restaurants like Mr. Biggs, KFC, PIZZA, DOMINO'S and NANDOS are not shielded from these economic meltdown. Most of their outlets have been abandoned or locked permanently without signs of businesses. In Nigeria, the only indigenous fast food restaurant listed in the Nigeria Stock Exchange known as Tantalizers posted a dismal performance in the market last year and plans to undertake a sale -and-lease back arrangement on some of its assets to raise working capital. It experienced about 86\% increase in net loss last year that was estimated at about N564.82 million. The company's audited report of 2013 shows turnover drop from N41.20 Billion in 2012 to N3.48 Billion in 2013. Gross profit declined from N1.9 Billion to N1.56 Billion. Operating cost increased from N243.4 million to N395.54 million, loss before tax doubled from N263.8 million to N598.45 million; while loss after tax increased from N303.47 million to N564.82 million. This is incredible and represents a total collapse of the firm. But the firm is not alone in this outbreak against the industry, others are suffering in silence.

Ayeni (2016) further notes that many efforts have been made by industry players and individual firms to overcome this melt down and unimaginable outbreak in the industry; some of these efforts according to Ayeni (2016) include: (1) Advertising and sales promotion activities; (2) closing some unprofitable outlets; (3) selling off equity shares to other investors; (4) listing in the second tier stock exchange market; (5) leasing and buying back arrangements; (6) Training and retraining of service personnel; (7) recruiting experienced chefs; (8) introduction of new menus both local and continental; and (9) buying raw foods directly from farmers, the fast food restaurants are still not attracting profitable patronage especially in Abuja, hence the gap. To close the gap, there is the need to develop a SERVICES QUALITY MODEL to salvage the industry.

\section{Objectives of the Study}

The objective of the study is to develop a Model for rendering quality services in Fast Food Restaurants in Abuja so as to attract the patronage of youths profitably. A Model is a simplified representation of a larger system. It can also be seen as a plan or strategy to overcome a problem such as in Marketing. More specifically, the Model is to articulate and present Marketing activities summarized under the major parameters used in measuring services quality. The need for this Model is premised on the fact that several efforts have been made by players in the industry to savage it but to no avail. Some of these efforts include advertising, interior/ exterior decorations and business diversification.

\section{Methodology}

To realize the objectives of this study, the Arms Chair and the Survey methods were adopted for gathering the needed data for this study ( Sharma: (2010). For the Arms Chair, the internet, text books and journals were utilized to gather secondary data. Primary data were gathered from consumers of Fast Food Restaurants in Abuja through Survey. This was achieved by utilizing the Yaro Yamen's formula (Baridam: 1995). Hence, at a convenience level of 0.05 (95\%), a sample size of 400 was realized from a population of 432,000 youths who represents about $72.0 \%$ of the population of Abuja. The questionnaires were distributed personally to the respondents by the researchers who spent about two (2) weeks in the field. The respondents were located at fast food restaurants and major drinking bars. The Quota or ratio sampling method was used to assign copies of the questionnaire to four major divisions of FCT which include (a) Kubwa/ Bwari Area: 80 (20\%) Questionnaires (b) Wuse/ Berger/Jabi/ Utako Area: 120 (30\%), (c) Maitama/ Asokoro/ Garki: 160 (40\%); and (d) Gwagwalada/ Kuje Area: 4 (10\%). All the questionnaires were properly filled and returned given the concerted efforts by the Researchers. Data collected were tabulated and analyzed using the percentage method. The result of the data collected and analyzed form the basis of the discursions below.

\section{Empirical Framew ork}

Food is very essential to human life and growth. The youths need food for their growth and development. Berger, et. al (1993) states that the youths are very busy in their academic pursuit and professional endeavors. They are mostly not with their wives or parents, yet they must eat. This therefore gives a developmental leverage to the fast food restaurant especially in Abuja where the population of the youths is increasing on daily basis. It also signifies that the need for food is unseasonal because life and growth cannot be sustained without food. Furthermore given the acute 
environmental pollution in Abuja for instance, the best place to get healthy and nutritious food is in a fast food restaurant (Tcvetkova: 2017).

Fast food restaurant is a public place or premises were food prepared and served quickly can be purchased and consumed. Fast food restaurant originated in Paris France in 1765 by a Frenchman called Mr. A. Boulanger who started as a soup vendor with signs such as RESTORATURES meaning 'Restaurants' on his door. That signs referred to the availability of soups and broths within. From there, restaurant denote a public eating place in English, French Dutch, Danish, Norwegian, Romania and many other languages with minor variations. In Nigeria, the first fast food restaurant is Mr. Biggs owned by United African Company (UAC). It started as a coffee shop inside Kingsway Department Stores Lagos in 1960s. In 1973, the coffee shop was rebranded as Kingsway Rendezvous and later Mr. Biggs in 1986. There was a rapid expansion in the fast food industry. In fact, in early 1990, many fast food restaurants have sprung up in major cities in Nigeria. Abuja was not left because of the relocation of FCT to Abuja. This necessitated the formation of the Association of Fast Food and Confectioneries of Nigeria (AFFCON). In the last conference of the Association in 2017, the National President Mrs. Bose Ayeni reports that the association is contributing about N250 Billion revenue to the Government through taxes and employs about 500,000 persons at all level. But despite these Economic Developmental Contributions, the Association is facing a lot of challenges. Some of these challenges according to Ayeni (2017) include: (1) Insecurity in the country; (2) inflation; (3) Exchange Rate problems; (4) High interest rate by Banks; (5) Non diversification opportunities in the economy; (6) lack of training; (7) lack of corporate governance such as high tax; (8) lack of Modern technology; (9) problem of ownership structure; (10) inappropriate business model; (11) increasing number and the improved services by "mama put"; (12) complaint of obesity and health related problems caused by fast food; and (13) No Standard because of influx of members.

\section{Conceptual Framew ork}

Restaurants offer services. By services we mean intangible offers that satisfy needs (Zeithaml, and Bitner: 2000). Restaurant services satisfy the need for food which develops as a result of the existence of hunger. It is worthy to note that though the food offered to eradicate hunger is tangible, the level of Satisfaction derivable from consuming the Food is intangible, yet this level of satisfaction is the main reason for patronage of Fast Food Restaurant. Cowell in Jobber (2004) States that what is significant about services is the relative dominance of intangible attributes in the makeup of the 'service product'. It is based on this that Palmer (2005) notes that Services are special kind of products that require special understanding and special marketing efforts. Services such as Restaurants (Foods) contain a combination of tangible and intangible attributes. Generally, services have unique characteristic that distinguish them from goods. These features are considered strictly when designing marketing programmes for any services. They include: intangibility, inseparability, variability and perish ability. These features are defined using Figure 1 below.

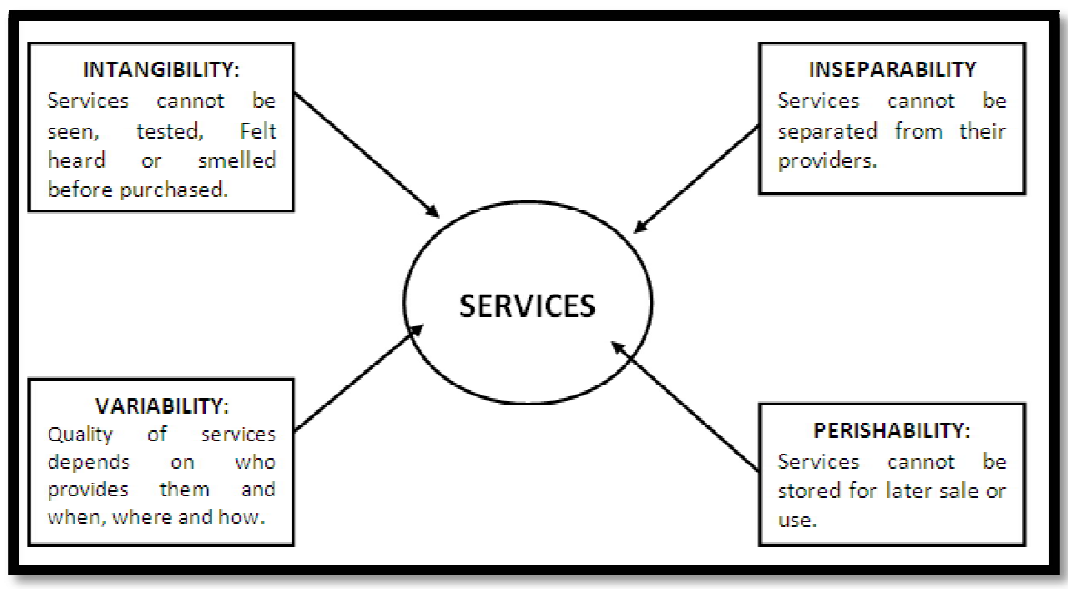

Figure 1: Four Basic Features or Characteristics of Services Adopted from Kotler and Armstrong 205:258

\section{Measuring Of Services Quality}

Parasuraman, Zeithaml and Berry (1985) state that a scale called SERVQUAL has been developed to aid the measurement of service quality based on five criteria: reliability, responsiveness, tangibles, assurance and Empathy. These criteria also form the basis for developing the questionnaire for this study.

\section{Data Analysis and Explanation}

For convenience, the data presented for this study are presented in two sections. The first section is principally aimed to ascertain the respondent's personal dispositions with regards to patronage for fast food restaurant. The generated data for their section and analyzed using the percentage method is as tabulated and presented as follows:

\section{Analysis of Data for Section a of the Questionnaire}




\begin{tabular}{|c|c|c|c|c|c|c|c|}
\hline \multirow[t]{2}{*}{ S/ NO } & \multirow[t]{2}{*}{ Questions } & \multicolumn{6}{|c|}{ Options } \\
\hline & & A & B & C & D & $\mathbf{E}$ & $\mathbf{F}$ \\
\hline \multirow[t]{2}{*}{1} & \multirow[t]{2}{*}{ Employment Status } & - & 52 & 8 & 100 & 240 & \\
\hline & & - & $13.0 \%$ & $2.0 \%$ & $25.0 \%$ & $\begin{array}{c}60.0 \\
\%\end{array}$ & \\
\hline \multirow[t]{2}{*}{2} & \multirow[t]{2}{*}{ Residential Area } & 80 & 120 & 160 & 40 & - & \\
\hline & & $20.0 \%$ & $30.0 \%$ & $40.0 \%$ & $10.0 \%$ & - & \\
\hline \multirow[t]{2}{*}{3} & \multirow[t]{2}{*}{ Age Bracket } & - & 130 & 170 & 50 & 50 & \\
\hline & & - & $32.5 \%$ & $42.5 \%$ & $12.5 \%$ & $\begin{array}{c}12.5 \\
\%\end{array}$ & \\
\hline \multirow[t]{2}{*}{4} & \multirow[t]{2}{*}{ Patronage for Fast Food Restaurant } & 20 & 50 & 190 & 14 & - & \\
\hline & & $5.0 \%$ & $12.5 \%$ & $47.5 \%$ & $3.5 \%$ & - & \\
\hline \multirow[t]{2}{*}{5} & \multirow{2}{*}{ Motivation for Fast Food Restaurant } & 30 & - & 230 & 100 & 30 & 10 \\
\hline & & $7.5 \%$ & - & $57.5 \%$ & $2.5 \%$ & $7.5 \%$ & $2.5 \%$ \\
\hline \multirow[t]{2}{*}{6} & \multirow{2}{*}{$\begin{array}{l}\text { Preference for a Fast Food } \\
\text { Restaurant }\end{array}$} & 194 & 206 & - & - & - & - \\
\hline & & $48.5 \%$ & $51.5 \%$ & - & - & - & - \\
\hline \multirow[t]{2}{*}{7} & \multirow{2}{*}{$\begin{array}{l}\text { Willingness to recommend a Fast } \\
\text { Food Restaurant }\end{array}$} & 340 & 60 & 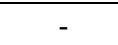 & - & - & - \\
\hline & & $85.5 \%$ & $15 \%$ & - & - & - & - \\
\hline
\end{tabular}

Table 1: Data Analysis for section 'A'

Source: Primary Data by the Researchers

\subsection{Explaination for Data In Table 1}

\subsubsection{Employment Status}

From Table 1 above, $13.0 \%$ of the respondents are either undergraduates or postgraduates; $2.0 \%$ are unemployed: $25 \%$ are self employed; while $60 \%$ are employed. This means that a higher percentage of the population has higher economic power to patronize fast food restaurants.

\subsubsection{Residential Area}

From Table 1, 20.0\% of the respondents reside in Kubwa/ Bwari Area; 30.0\% reside in Wuse/ Berger/ Jabi/ Utako are; $40.0 \%$ reside in Maitama/ Asokoro/ Garki area; while 10.0\% resides in Gwagwalada/ Kuje areas.

\subsubsection{Age Bracket}

From Table 1, 32.5\% are within the age bracket of 21 - 30 years; $42.5 \%$ are within the bracket of 31 - 35 years; $12.5 \%$ are within the age of 36 - 40 years and another $12.5 \%$ are within $41-45$ years. This shows that all the respondents are youths, thus ascribing higher credence and reliability to the data obtained through their responses.

\subsubsection{Patronage for Fast Food Restaurants}

From the Table 1 above $5.0 \%$ patronize Fast Food Restaurants very often, $12.5 \%$ patronize often; $47.5 \%$ patronize rarely; while $35.0 \%$ patronize very rarely. The implication of this is that the patronage rate is very low despite the need for the product and higher income in their disposal since they are employed.

\subsubsection{Motivation for Patronage for Fast Food Restaurant}

From Table 1 above, 7.5\% of the respondent are motivated to patronizing fast food restaurant because of lack of knowledge for cooking; $57.5 \%$ are motivated by no time to cook; $25.0 \%$ are motivated by the need to socialize with others; $7.5 \%$ are motivated by being in a hurry to stop hunger while $2.5 \%$ are motivated by the need to show or maintain social class. This is an opportunity to utilize the marketing tools for customer patronage.

\subsubsection{Preference for A Fast Food Restaurant}

From Table 1 above, $48.5 \%$ of the respondents have preference for a restaurant while $51.5 \%$ do not have preference for a particular restaurant. This means that the marketing efforts of the restaurant operators are weak.

\subsubsection{Willingness to Recommend a Fast Food Restaurant}

From Table 1 above, $85.5 \%$ of the respondents said they are willing to recommend a fast food restaurant while $15.0 \%$ said they are not willing to recommend any fast food restaurant to anybody.

\subsubsection{Factors That Motivate Preference and Willingness to Recommend A Fast Food Restaurant}

From the responses by the respondents, a summary of the factors that motivate preference for Fast Food Restaurants and willingness to recommend such fast food restaurants to others include:(a) The food is always fresh and not left over; (a)The ice cream is always very fresh and special; (c) Food is good, tasty and neatly prepared; (d) Very neat and good environment; (e) Availability of good food and choice drinks for customers ; and (f) Service personnel are always very friendly. 
9.2. Analysis of Data for Section B of the Questionnaire

\begin{tabular}{|c|c|c|c|c|c|}
\hline SA & A & DA & SDA & \multicolumn{2}{|c|}{ UND } \\
\hline 1a & $230(57.5 \%)$ & $150(37.5 \%)$ & $20(5.0 \%)$ & & \\
\hline b & $300(75.0 \%)$ & $80(20.0 \%)$ & $20(5.0 \%)$ & & \\
\hline c & $235(58.8 \%)$ & $160(40.0 \%)$ & $5(1.25 \%)$ & & \\
\hline 2a & $225(56.0 \%)$ & $85(21.25 \%)$ & $80(20.0 \%)$ & $10(2.5 \%)$ & \\
\hline b & $220(55.0 \%)$ & $100(25.0 \%)$ & $70(17.5 \%)$ & $10(2.5 \%)$ & \\
\hline c & $205(51.25 \%)$ & $80(20.0 \%)$ & $75(18.75 \%)$ & $30(7.5 \%)$ & $10(2.5 \%)$ \\
\hline 3a & $226(56.5 \%)$ & $144(36.0 \%)$ & $15(3.75 \%)$ & $15(3.75 \%)$ & \\
\hline b & $230(57.5 \%)$ & $120(30.0 \%)$ & $45(11.25 \%)$ & $5(1.25 \%)$ & \\
\hline c & $240(60.0 \%)$ & $135(33.75 \%)$ & $15(3.75 \%)$ & $10(2.5 \%)$ & \\
\hline d & $226(56.5 \%)$ & $144(36.0 \%)$ & $15(3.75 \%)$ & $15(3.75 \%)$ & \\
\hline 4a & $226(56.5 \%)$ & $144(36.0 \%)$ & $20(5.0 \%)$ & $10(2.5 \%)$ & \\
\hline b & $235(58.75 \%)$ & $70(17.5 \%)$ & $65(16.25 \%)$ & $20(5.0 \%)$ & $10(2.5 \%)$ \\
\hline c & $235(58.75 \%)$ & $65(16.25 \%)$ & $70(17.5 \%)$ & $25(6.25 \%)$ & $5(1.25 \%)$ \\
\hline 5a & $80(20.0 \%)$ & $280(70.0 \%)$ & $30(7.5 \%)$ & $10(2.5 \%)$ & \\
\hline b & $75(18.75 \%)$ & $270(67.5 \%)$ & $45(11.25 \%)$ & $10(2.5 \%)$ & \\
\hline c & $90(22.5 \%)$ & $260(65.0 \%)$ & $40(10.0 \%)$ & $15(3.75 \%)$ & \\
\hline
\end{tabular}

Table 2: Data Analysis for Section 'B'

SOURCE: Primary Data by the Researchers

\subsection{Explaination for Data in Table 2}

This table explains the factors that constitute the quality of the services by a Fast Food Restaurant. Berry and Parasuraman (1991) state that the factors stated also forms the basis for attracting patronage for fast food restaurants from the customers. From Table 2 above, $57.5 \%$ strongly agree that quality food that is always warm and fresh is a good factor, $37.5 \%$ agreed, while $5.0 \%$ disagreed. For availability of food and cold drinks, $75.0 \%$ strongly agree, $20.0 \%$ agree while $5.0 \%$ disagree; for less expensive and moderate price food/drinks, $58.8 \%$ strongly agreed, $40.0 \%$ agreed while $1.25 \%$ disagreed. For very prompt services, $56.0 \%$ strongly agree, $21.25 \%$ agree, $20.0 \%$ disagree while $2.5 \%$ strongly disagree, for less steps to offer services; $55.0 \%$ strongly agree, $25.0 \%$ agree, $17.5 \%$ disagree while $2.5 \%$ strongly disagree. For prompt response to complaints, $51.25 \%$ strongly agree, $20.0 \%$ agree, $18.75 \%$ disagree, and $7.50 \%$ strongly disagree while $2.5 \%$ are undecided. For attractive physical facilities; $56.5 \%$ strongly agree, $36.0 \%$ agree, $3.75 \%$ disagree while $3.75 \%$ strongly disagree. For neat and cool environment; $57.5 \%$ strongly agree, $30.0 \%$ agree, $11.25 \%$ disagree while $1.25 \%$ are undecided; for neat and attractive service personnel; $60.0 \%$ strongly agree, $33.77 \%$ agree, $3.75 \%$ disagree while $2.5 \%$ are undecided. For the availability of electricity, parking space and guaranteed security; $56.5 \%$ strongly agree, $36.0 \%$ agree, $3.73 \%$ disagree while another $3.75 \%$ strongly disagreed. For employees prove of competence, $56.5 \%$ strongly agree, $36.0 \%$ agree, $5.0 \%$ disagree while $2.5 \%$ strongly disagree. For confidence for patronage, $58.75 \%$ strongly agree, $17.5 \%$ agree, $16.25 \%$ disagree, $15.0 \%$ strongly disagree while $2.5 \%$ are undecided. Courtesy by employees, $58.75 \%$ strongly agree, $16.25 \%$ agree, $17.5 \%$ disagree, $6.25 \%$ strongly disagree, while $1.25 \%$ are undecided. For caring and friendly services employees, $20.0 \%$ strongly agree, $70.0 \%$ agree, $7.5 \%$ disagree while $2.5 \%$ strongly disagree. For individualized attention by customers, $18.75 \%$ strongly agree, $67.5 \%$ agree, $11.25 \%$ disagree while $2.5 \%$ strongly disagree. For employees understanding of customer's problems and feelings, $22.5 \%$ strongly agree, $65.0 \%$ agree, $10.0 \%$ disagree $3.75 \%$ strongly disagree.

\section{Summary of Finding}

From the analysis of data above, the following facts emerged:

- Greater numbers of the customers are employed in the fast food industry.

- Most of the customers are youths within the age bracket of 21 - 45 years.

- Recently, greater percentages of the customers rarely patronize fast food restaurants.

- Some of the factors responsible for lower patronage for fast food restaurants are;

- Insecurity in the country which is responsible for the avoidance of public places by most persons;

- Inflation

- High cost of food in fast food restaurants as a result of higher cost of operations generated through factors such as high exchange rate and high interest rate and taxed;

- Inappropriate business model;

- Over dominant of "Mama put" operators;

- Lack of modern technology;

- Fear of health related problems such as obesity, fat.

- No professional standard and code, thus the influx of members.

- The few that are still patronizing fast food restaurants do so mainly because they don't have time to cook or only when just to socialize with others. 
- Most of the customers do not have preference for any particular Fast Food Restaurant because the outlets are almost the same.

- Customers that have preference and willing to recommend Fast Food Restaurant are motivated by factors such as:

- The food is always fresh and not left over.

- The ice cream is always very fresh and special.

- Their food has good taste.

- The environment is very neat and cold.

- Availability of varieties of food and drinks for customers.

- Services personnel are always very friendly.

- Most customers strongly agree that the quality of food that is warm and fresh attracts customers to fast food restaurants.

- Availability of food and cold drinks attracts customers to fast food restaurant.

- Most customers strongly agree that they are attracted to fast food restaurants by less expensive or moderately priced foods and drinks.

- Most customers strongly agree that they are attracted to fast food restaurants because of very prompt services rendered by the restaurant.

- Most customers strongly agree that less steps to offer and receive services attract them to fast food restaurants;

- Most customers strongly agree that prompt response to customers' complaints attract customers to fast food restaurants;

- Most customers strongly agree that the existence or visibility of attractive physical facilities attract customers.

- Most customers strongly agree that neat and cool environment attract them to fast food restaurants.

- Most of the customers strongly agree that neat and attractive service personnel attract customers to fast food restaurant.

\section{Model of Service Quality for Fast Food Restaurant in Abuja, Nigeria}

Utilizing the facts above, a new Model of Service Quality for Fast Food Restaurant in Abuja, Nigeria is recommended as follows:

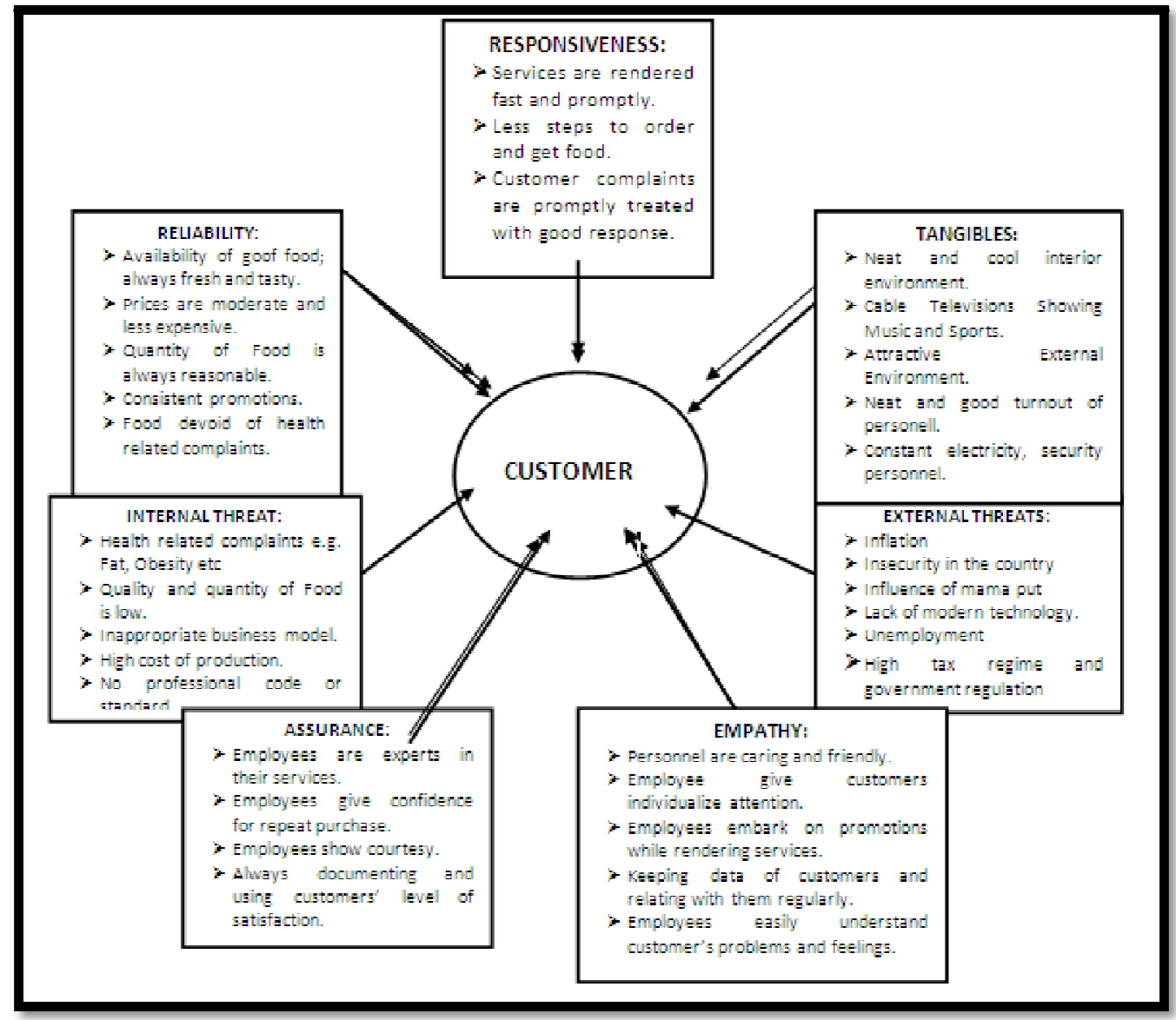

Figure 2: Model of Service Quality for Fast Food Restaurant in Abuja, Nigeria Source: Researchers' Desk

\section{Explanation for the Service Quality Model for Fast Food Restaurants In Abuja}


Figure 2 above shows a prospective and a potential customer for fast food restaurants in Abuja in the midst of pressures capable of changing their purchase behaviors. These factors are summarized under: Reliability, Responsiveness, Tangibles, Assurance and Empathy. In these factors are Marketing tools for Fast Food Restaurant Services and other factors identified by the respondents through the Secondary/ Primary data obtained for the study. The factors include:

\section{Reliability}

- Availability of good food. This has to do with ensuring that fresh and tasty foods are always available for customers.

- Prices of food and drinks sold by fast food restaurants must be moderate or less expensive. There is no need increasing the prices so more than what is obtainable in the open market or other drinking bars.

- The Quality of the food served must be reasonable to satisfy an average eater. It is better for the customer to eatsatisfied and pay higher than to eat unsatisfied and pay lower.

- Consistent promotional activities especially through Advertising, sales promotion, public relations personal selling must be executed.

- Avoid selling food that could attract health related complaints. Examples are rotten meat/ Chicken, too much oil and fat.

\section{Responsiveness}

- Customers order must be delivered fast or promptly.

- The steps for placing an order and receiving the food must be reduced. It is advisable for the customer to sit down comfortably; the service/ food provider will go to the customer, take the order and serve immediately. A hungry customer cannot afford to stand for a longer time waiting to place an order and still wait to carry the food served.

- There must be a provision to receive customer complaint. These complaints must be promptly treated with good response.

\section{Tangibles}

- The interior of the eating environment must always be neat and cool.

- The eating environment must have cable television's that will show music, films and even sports when there is a high profile football match or sports competitions.

- The external environment must be neat and well decorated with good packing space.

- The service personnel will always be neat and very well turned out.

- There must be constant electricity. The electric generating machines and security personnel must be strategically positioned to prove the restaurant's ability to render quality service.

\section{Assurance}

- The employees must always prove that they are competent in rendering good services.

- Employees should give customers the confidence to make repeat purchase.

- Employees must always show courtesy when dealing with customers. On no account should the employee get angry over customers behavior.

- Employees should make efforts to document customers' level of satisfaction.

\section{Empathy}

- Service personnel must always be caring and friendly.

- Employees must always give customers individualized attention.

- The service employees should be utilized to execute personnel selling as a promotional effort. This they can achieve while rendering service.

- There is need to keep data of customer's and relate with them regularly through phone.

- Employees should always make effort to understand customers' problems and feelings. Customers should be asked to explain the taste and overall quality of the food and how satisfied they are.

Apart from the factors above, there are two factors that are termed internal and external threats with single arrows pointing to the customer. This signifies threats in the general business environment which are beyond the control of the fast food restaurant operators, and threats emanating from customer's complaint. Interestingly, these two different types of threats can be overcomed by the main factors that determine services quality (Reliability, Responsiveness, Tangibles, Assurance and Empathy). The threat factors include:

\section{External Threats}

- Poverty and high cost of living as a result of inflation.

- Insecurity in the country leading to many people avoiding public places.

- Influence of the proliferation of "Mama Put" in the locks and crannies of the streets.

- Lack of modern technology to overcome some problems like storage facilities, oven, Rosters, preservers, washing and drying machines etc.

- Unemployment in the country, hence the purchasing power of the youths is reduced.

- High tax regimes and influence of government regulation on fast food restaurants in Abuja. 


\section{Internal Threats}

- Health related complaints by customers such as fat or rotten meat/ fish and other soup or stew condiments

- Quality of food

- Inappropriate business model for fast food restaurant.

- High cost of production.

- No professional code or standard.

\section{Summary}

Every business environment is turbulent; the fast food restaurant industry is not exceptional, but special. Special in the sense that their services (which is the provision of food) to customers is most essential, yet there is no prohibition of entry and exit to and fro the industry; there is always no standard or identifiable business standard for the fast food industry. No wonder there is weak patronage for fast food restaurants despite the increasing population of youths in Abuja. This therefore requires the development of an appropriate model that can attract customer satisfaction. To obtain a more reliable data, customers to fast food restaurants in Abuja comprising of mostly youths were used as respondents. This gave more credence to the data obtained and which was used to develop a model for fast food industry in Abuja.

\section{Conclusion}

The Fast Food Restaurant is very viable given the large markets and the nature of the product (food) whose demand is ever-existing and increasing. The viability of the market is dependent on the ability of the Marketer in Abuja to utilize the Service Quality Model for Fast Food Restaurants. This will attract customers profitably to the Restaurant.

\section{References}

i. Asubontang, P, McCleary, K.J., and Swan, J.E, (1996); SERVQUAL revisited. A Critical Review of Service Quality. The Journal of Services Marketing.

ii. Anyanwu, A. and Inyanga, JI.N. (2006); Marketing and Society. Owerri, Avan Global Publications

iii. Kotler P. and Kotler, K. (2006); Marketing, Management 12 ${ }^{\text {th }}$ edition, New Delhi, Pearson Education.

iv. Parasuraman, A. ZeilthamL, V. and Berry, L. (1985); A Conceptual model of service quality and it's implication. Journal of Marketing.

v. Rai, A. (2008); Customer Relationship Management: Concepts and cases. PHI learning.

vi. Tse, D. and Wilton, P. (1988); Model of customer satisfaction. An Extension. Journal of Marketing Research.

vii. Tevetkova, D. and Aarnio, D. (2017); Customer Satisfaction and Service Quality at Fafa's Restaurant. www.servicequality.retrieved 15th March, 2018.

viii. Zalatar, W.F (2017); Service Quality and Customer Satisfaction in Fast Food Restaurants; A customer comparison using Discriminate Analysis. www.servicequality.retrieved 15th March, 2018.

ix. Belch G.E and Belch M.A (2007); Advertising and promotion: An integrated marketing communication perspective, 7th edition Boston McGraw Hill Irwin.

x. Berry L. and Parasuraman A. (1991); Marketing Services: Competing through Quality. New York, The Free Press.

xi. Hawkins D.I., Best R.J and Convey K.A (2001); Consumer Behavior: Building Marketing Strategy, 8th edition. Boston, McGraw-Hill.

xii. Kotler P. and Armstrong (2005); Principles of Marketing, $11^{\text {th }}$ edition, New Delhi, Prentice-Hall of India.

xiii. Onah, J.O and Thomas, M.J (2004); Marketing Management: Strategies and cases, $2^{\text {nd }}$ edition, Enugu Institute of Development Studies, University of Nigeria.

xiv. Palmer A. (2005); Principles of Services Marketing. $4^{\text {th }}$ edition. London, McGraw-Hill.

xv. Stanton, W.J (1981); Fundamental of Marketing. $6^{\text {th }}$ edition. Auckland. McGraw-Hill International company.

xvi. Zeithaml, V.A., and Bitner, M.J. (2000); Services Marketing: Integrating Customer Focus Across the Firm, $2^{\text {nd }}$ edition, Boston Irwin McGraw Hill.

xvii. Griseri, P. and Seppala, N. (2010); Business Ethics and Corporate Social Responsibility. U.K, South-Western Language Learning.

xviii. Lancaster, G. and Massgham, L. (2001); Marketing Management 3rd edition London. McGraw Hill.

xix. Jobber, D. (2004); Principles and Practice of Marketing. $4^{\text {th }}$ edition London, McGraw Hill.

xx. Baridam, D.M. (1995); Research Methods in Administrative Sciences. $2^{\text {nd }}$ edition; Port Harcourt, Paragraphics.

xxi. Sharma, D.D. (2010); Marketing Research: Principles, Applications and Cases. New Delhi, Sultan Chand and Sons.

xxii. Etzel M.J., Walker, B.J. Stanto, W.J. and Pandit, A. (2006). Marketing: Delhi, Taka McGraw Hill Publishing Company Limited.

xxiii. Jefkins, F. and Yaldin, O. (1998); Public Relations. $5^{\text {th }}$ edition Harlow, Prentice Hall. 


\section{Dear respondent,}

The questions underneath are for the purpose of a research effort titled "service Quality model for attracting patronage from youth for fast food Restaurants in Abuja". You are kindly requested to tick the column that represents your opinion or answer. Please be assured that your answer will be treated with the strict confidence.

\section{Section A}

1.Employment Status:

a. seeking for admission () b. undergraduate/ post graduate ()

c. unemployed () d. self employed（） e.employed ()

2. Which part of Abuja do you reside/ work?
(a) Kubwa/ Bwari
(b). Wuse/ Berger/ Jabi/ Utako
(c.) Maitama/ Asokoro/ Garki
(D.) Gwagwalada/ Kuje

3. Age Bracket:
(a). 15 -20 yrs
(b). 21 -30 yrs
(c). 31 - $35 \mathrm{yrs}$
(d). 36 - 40 yrs
(e) $.41-45 \mathrm{yrs}$

4. How often do you patronize fast food outlets in Abuja?
(a.) very often
( b.) Often
(c.) Rare
(d.) very rare
(e.) not at all

5. what actually motivate (s) your patronage for fast food restaurant? (a). lack of knowledge for cooking (b). lack of money for cooking (c.) no time to cook (d.) To socialize with others (e.) In a hurry to stop hunger ( f). Show or maintain social class g. (g) Others, Pls specify.

6. Do you have preference for a particular fast food outlet? a. yes b. no

7. Can you willingly and sincerely recommend your choice of fast food outlets to your friends, relations? $\quad$ a. yes b. no

8. In your candid opinion, please state clearly the factors that motivate you to prefer and willing to recommend your choice of fast food restaurant to others

Section B

\begin{tabular}{|c|c|c|c|c|c|}
\hline \multirow[t]{2}{*}{ FACTORS } & $\begin{array}{l}\text { Strongly } \\
\text { Agree } \\
\text { (SA) }\end{array}$ & $\begin{array}{c}\text { Agree } \\
\text { (AG) }\end{array}$ & $\begin{array}{c}\text { Disagree } \\
\text { DA }\end{array}$ & $\begin{array}{l}\text { Strongly } \\
\text { Disagree } \\
\text { SDA } \\
\end{array}$ & $\begin{array}{l}\text { Undecided } \\
\text { UND }\end{array}$ \\
\hline & $\mathbf{A}$ & B & C & D & $\mathbf{E}$ \\
\hline $\begin{array}{l}\text { From your experience, your } \\
\text { recommended fast food outlets should } \\
\text { have the following qualities: }\end{array}$ & & & & & \\
\hline $\begin{array}{l}\text { RELIABILITY: } \\
\text {-high quality food always warm and fresh } \\
\text { - availability of cold drinks; always } \\
\text { available food/ drinks of customer choice } \\
\text {-moderate price/ less expensive }\end{array}$ & & & & & \\
\hline $\begin{array}{l}\text { RESPONSIVENESS } \\
\text { - very prompt services } \\
\text {-less steps to offer and consume service } \\
\text { - Employees treat your complaints or } \\
\text { request promptly. }\end{array}$ & & & & & \\
\hline $\begin{array}{l}\text { TANGIBLES } \\
\text {-Physical facilities are attractive } \\
\text {-The environment is very neat and always } \\
\text { cool } \\
\text {-Service personnel are always neat and } \\
\text { attractive. } \\
\text {-Electricity, Security and parking space } \\
\text { are always available. }\end{array}$ & & & & & \\
\hline FACTORS & $\begin{array}{l}\text { Strongly } \\
\text { Agree }\end{array}$ & $\begin{array}{c}\text { Agree } \\
\text { (AG) }\end{array}$ & $\begin{array}{c}\text { Disagree } \\
\text { DA }\end{array}$ & $\begin{array}{l}\text { Strongly } \\
\text { Disagree }\end{array}$ & $\begin{array}{c}\text { Undecided } \\
\text { UND }\end{array}$ \\
\hline
\end{tabular}




\begin{tabular}{|l|c|c|c|c|c|}
\hline & (SA) & & & SDA & \\
\cline { 2 - 5 } & A & B & C & D & E \\
\hline ASSURANCE/COMPETENCE & & & & & \\
-Employees are experts in their service. & & & & & \\
- Employees will always give you & & & & & \\
confidence for repeat patronage. & & & & & \\
- Employees show courtesy. & & & & & \\
\hline $\begin{array}{l}\text { EMPATHY } \\
\text {-Employees are caring and friendly } \\
\text { - Employee give every customer } \\
\text { individualized attention. } \\
\text { - Employees easily understand customers' } \\
\text { problems and feelings. }\end{array}$ & & & & & \\
\hline
\end{tabular}

Table 3 